\title{
Dissolved beryllium isotopes distribution in the northern South China Sea
}

\author{
LIPING ZHOU ${ }^{1,2}$, WEIYUAN KONG ${ }^{1}$, DIDIER BOURLÈS ${ }^{3}$ \\ ${ }^{1}$ Department of Geography, Peking University, China \\ lpzhou@pku.edu.cn, wykong@pku.edu.cn \\ ${ }^{2}$ Institute of Ocean Research, Peking University, China \\ ${ }^{3}$ Aix-Marseille Université, CNRS, Col. de France, IRD, \\ INRAE, UM 34 CEREGE, 13545 Aix en Provence, \\ France.bourles@cerege.fr
}

Atmospheric cosmogenic radionuclide ${ }^{10} \mathrm{Be}$ and stable isotope ${ }^{9} \mathrm{Be}$ in seawater may serve as a quasi-conservative tracer for water mass mixing and freshwater input, but such data are rare. Here we present dissolved ${ }^{10} \mathrm{Be}$ and ${ }^{9} \mathrm{Be}$ concentrations of a section from Pearl River estuary through shelf areas to deep water, as well as of the surface water in the northern South China Sea (SCS). Surface water ${ }^{9} \mathrm{Be}$ concentrations of all stations range from $8.8 \mathrm{pmol} / \mathrm{kg}$ to 43.6 $\mathrm{pmol} / \mathrm{kg}$. The maximum ${ }^{9} \mathrm{Be}$ concentration occurs near the Pearl River estuary and forms a notably tongue-shaped high ${ }^{9} \mathrm{Be}$ zone. There is a trend of ${ }^{9} \mathrm{Be}$ decrease from northwestern coast towards the southeastern inner basin. Dissolved ${ }^{10} \mathrm{Be}$ concentrations of surface water vary between 118 atoms $/ \mathrm{kg}$ and 576 atoms $/ \mathrm{kg}$ and show a decreasing trend from east to northwest. Patterns of vertical distribution of the dissolved ${ }^{9} \mathrm{Be}$ and ${ }^{10} \mathrm{Be}$ concentrations as well as ${ }^{10} \mathrm{Be} /{ }^{9} \mathrm{Be}$ ratios for the section vary with the water depth of the stations. Both surface ${ }^{9} \mathrm{Be}$ and ${ }^{10} \mathrm{Be}$ concentrations decrease southward from Pearl River estuary. Below surface water, ${ }^{9} \mathrm{Be}$ concentrations decrease southward while ${ }^{10} \mathrm{Be}$ concentrations increase slightly. At the most shallow site on the shelf, the ${ }^{9} \mathrm{Be}$ and ${ }^{10} \mathrm{Be}$ show inverse variation trends from surface to bottom: ${ }^{9} \mathrm{Be}$ concentrations increase by a factor of 2 from surface to bottom while ${ }^{10} \mathrm{Be}$ concentrations decrease from 458 atoms $/ \mathrm{g}$ to 182 atoms $/ \mathrm{g}$, this results in a sharp decrease of ${ }^{10} \mathrm{Be} /{ }^{9} \mathrm{Be}$ from $3.14 \times 10^{-8}$ to the lowest $0.61 \times 10^{-8}$. For the two deep stations in the SCS inner basin, ${ }^{9} \mathrm{Be}$ concentrations are doubled from surface to $\sim 500 \mathrm{~m}$ and remain constant at deeper depths, while ${ }^{10} \mathrm{Be}$ concentrations show an increasing trend towards bottom. The ${ }^{10} \mathrm{Be} /{ }^{9} \mathrm{Be}$ ratio at both stations increases with depth, apparently dominated by the ${ }^{10} \mathrm{Be}$ concentration. The ${ }^{10} \mathrm{Be} /{ }^{9} \mathrm{Be}$ for the water sample collected at $3040 \mathrm{~m}$ at Station SEATS is $9.57 \times 10^{-8}$. The distinct distributions of seawater Be isotopes in this study provide us an opportunity to further our understanding on their variations as a result of oceanographic processes such as freshwater input, mixing, bottom scavenging, and influence of intruded Kuroshio Current or deep boundary current. 